\title{
Rational Design, Synthesis, and Evaluation of Key Analogues of CC-1065 and the Duocarmycins
}

\author{
Mark S. Tichenor ${ }^{\dagger}, \operatorname{Karen}$ S. MacMillan ${ }^{\dagger}$, James S. Stover ${ }^{\dagger}$, Scott E. Wolkenberg ${ }^{\dagger}$, Maria G. \\ Pavani $\ddagger$, Lorenzo Zanella $\ddagger$, Abdel N. Zaid $\ddagger$, Gianpiero Spalluto $\ddagger$, Thomas J. Rayl ${ }^{\dagger}$, Inkyu \\ Hwang ${ }^{\dagger}$, Pier Giovanni Baraldi $\mp$, and Dale L. Boger ${ }^{\dagger}$ \\ $\dagger$ Department of Chemistry and the Skaggs Institute for Chemical Biology, The Scripps Research Institute, \\ 10550 North Torrey Pines Road, La Jolla, California 92037, E-mail: boger@ scripps.edu \\ $\$$ Dipartimento di Scienze Farmaceutiche, Università degli Studi di Ferrara, via Fossato di Mortara 17/19, \\ 44100, Ferrara, Italy
}

\section{Abstract}

The design, synthesis, and evaluation of a predictably more potent analogue of CC-1065 entailing the substitution replacement of a single skeleton atom in the alkylation subunit are disclosed and was conducted on the basis of design principles that emerged from a fundamental parabolic relationship between chemical reactivity and cytotoxic potency. Consistent with projections, the MeCTI (7methyl-1,2,8,8a-tetrahydrocyclopropa[c] thieno[3,2-e]indol-4-one) alkylation subunit as well as its isomer iso-MeCTI (6-methyl-1,2,8,8a-tetrahydrocyclopropa[c]thieno[2,3-e]indol-4-one) were found to be 5-6 times more stable than the MeCPI alkylation subunit found in CC-1065 and slightly more stable than even the DSA alkylation subunit found in duocarmycin SA placing it at the point of optimally balanced stability and reactivity for this class of antitumor agents. Their incorporation into the key analogues of the natural products provided derivatives that surpassed the potency of MeCPI derivatives (3-10 fold) matching or slightly exceeding the potency of the corresponding DSA derivatives consistent with projections made based on the parabolic relationship. Notable of these, MeCTI-TMI proved to be as potent or slightly more potent than the natural product duocarmycin SA

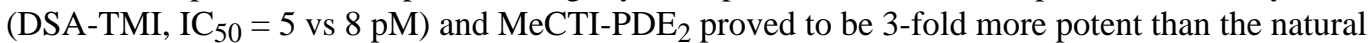
product CC-1065 (MeCPI-PDE $\left.2, \mathrm{IC}_{50}=7 \mathrm{vs} 20 \mathrm{pM}\right)$. Both exhibited efficiencies of DNA alkylation that correlate with this enhanced potency without impacting the intrinsic selectivity characteristic of this class of antitumor agents.

\section{Introduction}

CC-1065 1 (1) and duocarmycin SA (2) $)^{2}$ represent the key members of a small class of exceptionally potent naturally occurring antitumor agents ${ }^{1-4}$ that derive their biological properties through a now characteristic sequence-selective DNA alkylation reaction (Figure 1). ${ }^{5-9}$ Extensive investigations on the naturally occurring members of this class as well as their synthetic analogues have defined key and subtle features that contribute to their properties. 9,10 Most notable of these are the structural features that contribute to the AT-rich noncovalent binding selectivity dominating the alkylation selectivity, ${ }^{11}$ those that define the source of catalysis for the DNA alkylation reaction, ${ }^{12,13}$ and those that subtly impact the unusual and intrinsic stability of their alkylation subunits. $9,13,14$ 


\section{Results and Discussion}

\section{Design}

Throughout the course of our investigations, we have chronicled a direct relationship between the intrinsic chemical stability of the alkylation subunit and the cytotoxic potency of the resulting derivatives. ${ }^{15}$ Recently, a compilation of the data derived from more than 30 deepseated modifications resulted in the establishment of a well-defined parabolic relationship between the alkylation subunit reactivity and the resulting cytotoxic potency that spanned a $10^{4}-10^{6}$ range of reactivities and activities (Figure 2). ${ }^{16}$ Presumably, this fundamental relationship simply reflects the fact that the compound must be sufficiently stable to reach its biological target, yet remain sufficiently reactive to alkylate DNA once it does. Significantly, the work defined this optimal balance between reactivity and stability providing a fundamental design feature that is subject to investigational interrogation.

Herein, we report our first such efforts culminating in the synthesis and evaluation of 7methyl-1,2,8,8a-tetrahydrocyclopropa[c] thieno[3,2-e]indol-4-one (MeCTI, 3) as well as 6methyl-1,2,8,8a-tetrahydrocyclopropa[c] thieno[2,3-e]indol-4-one (iso-MeCTI, 4) and their incorporation into analogues of both CC-1065 and the duocarmycins (Figure 3). ${ }^{17}$ The design of MeCTI and the decision to invest in its exploration rested with expectations that it would be substantially more stable than the alkylation subunit found in CC-1065 (MeCPI, 5) leading to a substantially more potent CC-1065 analogue approaching the stability and activity of duocarmycin SA. Intuitively, this might be anticipated to arise from the strain release provided by a fused thiophene versus pyrrole which in turn may further benefit from the intrinsic electron-withdrawing character of a thiophene. More quantitatively, this increased stability could be approximated using semiempirical calculations (AM1, MNDO) for heats of reaction for hydride addition to the activated cyclopropane (Figure 3). Using this approximation, MeCTI was selected among several candidate alkylation subunits as being more stable than CBI (6, 1,2,9,9a-tetrahydrocyclopropa[ $c]$ benzo[ $e$ ]indol-4-one) and approaching or exceeding that of DSA (7) potentially approaching the optimal stability defined on the parabolic relationship. Significantly, MeCTI represents a single atom change in the backbone structure of the CC-1065 alkylation subunit that in turn was projected to provide a near optimal increase in stability and potency (Figure 4).

\section{Synthesis of $\mathrm{N}$-Boc-MeCTI}

Stobbe condensation of 4-methylthiophene-3-carboxaldehyde $(\mathbf{9}, 4$ equiv of $t$-BuOK, 6 equiv of diethyl succinate, $83^{\circ} \mathrm{C}, 1.5 \mathrm{~h}$ ) gave a mixture of half-esters 10 which were subjected to Friedel-Crafts acylation (excess $\mathrm{Ac}_{2} \mathrm{O} / \mathrm{NaOAc}, 140{ }^{\circ} \mathrm{C}, 5 \mathrm{~h}, 40 \%$ ) to provide $\mathbf{1 1}$ (Scheme 1). 18 Compound 11 was hydrolyzed to phenol 12 (1.1 equiv of $\mathrm{K}_{2} \mathrm{CO}_{3}, 78^{\circ} \mathrm{C}, 14 \mathrm{~h}, 83 \%$ ), which was protected as the benzyl ether 13 (1.2 equiv of $\mathrm{BnBr}, 1.2$ equiv of $\mathrm{K}_{2} \mathrm{CO}_{3}, 25^{\circ} \mathrm{C}, 5 \mathrm{~h}, 98 \%$ ). Subsequent hydrolysis of the ethyl ester ( 3 equiv of $\mathrm{LiOH}, 4: 1: 1 \mathrm{THF}-\mathrm{MeOH}-\mathrm{H}_{2} \mathrm{O}, 25^{\circ} \mathrm{C}, 18$ h, $98 \%$ ) followed by Curtius rearrangement of the resulting carboxylic acid $\mathbf{1 4}$ (1.2 equiv of DPPA, 1.2 equiv of $\mathrm{Et}_{3} \mathrm{~N}, 83{ }^{\circ} \mathrm{C}, 18 \mathrm{~h}, 76 \%$ ) provided carbamate $\mathbf{1 5}$. Regioselective acidcatalyzed C4-iodination ( 0.1 equiv of $\mathrm{H}_{2} \mathrm{SO}_{4}, 1.1$ equiv of $\mathrm{NIS}, 25^{\circ} \mathrm{C}, 2 \mathrm{~h}, 89 \%$ ) followed by carbamate alkylation of $\mathbf{1 6}$ with allyl bromide (1.2 equiv of $\mathrm{NaH}, 3$ equiv of allyl bromide, 25 ${ }^{\circ} \mathrm{C}, 3 \mathrm{~h}, 95 \%$ ) provided 17. 5-Exo-trig radical cyclization conducted in the presence of TEMPO $^{19}$ (2.7 equiv, 3 equiv of $\left(\mathrm{Me}_{3} \mathrm{Si}\right)_{3} \mathrm{SiH}, 100{ }^{\circ} \mathrm{C}, 5 \mathrm{~h}, 78 \%$ ) gave 18 in good yield whereas the more conventional use of $\mathrm{Bu}_{3} \mathrm{SnH}$ was unsuccessful. ${ }^{20} \mathrm{Zinc}$-mediated reductive cleavage of $\mathbf{1 8}$ (16 equiv of $\left.\mathrm{Zn}, 70^{\circ} \mathrm{C}, 3 \mathrm{~h}, 83 \%\right)$ followed by chlorination displacement of the released primary alcohol ( 2 equiv of $\mathrm{Ph}_{3} \mathrm{P}, 6$ equiv of $\mathrm{CCl}_{4}, 25^{\circ} \mathrm{C}, 20 \mathrm{~h}, 95 \%$ ) provided $\mathbf{2 0}$. Intermediate 20 was separated into its two enantiomers by resolution on a semipreparative Chiralcel ${ }^{\circledR}$ OD column (20\% $i$-PrOH/hexane, $\alpha=1.30) .{ }^{21}$ Hydrogenolysis of the benzyl ether (25\% aqueous $\mathrm{HCO}_{2} \mathrm{NH}_{4}, 10 \% \mathrm{Pd} / \mathrm{C}, 60^{\circ} \mathrm{C}, 2 \mathrm{~h}$ ) followed by immediate spirocyclization of the crude product 
by treatment with $\mathrm{DBU}$ (10 equiv, $\mathrm{DMF}-\mathrm{CH}_{3} \mathrm{CN}, 25^{\circ} \mathrm{C}, 10 \mathrm{~min}, 70 \%$ ) provided each enantiomer of $\mathbf{3}$.

\section{Synthesis of MeCTI-TMI, MeCTI-indole 2 and MeCTI-PDE 2}

Acid-catalyzed deprotection of $\mathbf{2 0}\left(4 \mathrm{~N} \mathrm{HCl}-\mathrm{EtOAc}, 25^{\circ} \mathrm{C}, 1 \mathrm{~h}\right)$ followed by coupling of the resulting hydrochloride salt with 5,6,7-trimethoxyindole-2-carboxylic acid $\left(\mathbf{2 2},{ }^{22} 4\right.$ equiv of EDCI, 2 equiv of $\mathrm{NaHCO}_{3}, 25^{\circ} \mathrm{C}, 15 \mathrm{~h}, 92 \%$ ) provided $\mathbf{2 3}$ (Scheme 2). Hydrogenolysis of the benzyl ether $\left(25 \%\right.$ aqueous $\left.\mathrm{HCO}_{2} \mathrm{NH}_{4}, 10 \% \mathrm{Pd} / \mathrm{C}, 25^{\circ} \mathrm{C}, 2 \mathrm{~h}, 83 \%\right)$ afforded 24 and its spirocyclization was effected by treatment with $\mathrm{DBU}$ ( 4 equiv, $\mathrm{DMF}-\mathrm{CH}_{3} \mathrm{CN}, 25^{\circ} \mathrm{C}, 10 \mathrm{~min}$, 70\%) providing 25.

A subtle modification of this sequence was used to access MeCTI-indole 2 and $\mathrm{MeCTI}_{2} \mathrm{PDE}_{2}$. Thus, acid-catalyzed deprotection of 21 ( $4 \mathrm{~N} \mathrm{HCl}-\mathrm{EtOAc}, 25^{\circ} \mathrm{C}, 1 \mathrm{~h}$ ) followed by coupling of the resulting hydrochloride salt with $\mathrm{PDE}_{2}-\mathrm{CO}_{2} \mathrm{H}(\mathbf{2 6})^{23}$ or indole $2-\mathrm{CO}_{2} \mathrm{H} \mathrm{(27)}$ (4 equiv of EDCI, 1.5 equiv of $\mathrm{RCO}_{2} \mathrm{H}, 25{ }^{\circ} \mathrm{C}, 0.5 \mathrm{~h}, 40-72 \%$ ) provided 28 and 29 (Scheme 3). This coupling with an alkylation subunit precursor in which the C5-benzyl ether was already removed permitted direct spirocyclization effected by treatment with $\mathrm{NaHCO}_{3}$ (4 equiv, 2:1 DMF- $\mathrm{H}_{2} \mathrm{O}, 25^{\circ} \mathrm{C}, 10 \mathrm{~min}, 46-81 \%$ ) providing $\mathbf{8}$ and $\mathbf{3 0}$.

\section{Synthesis of $\mathbf{N}$-Boc-iso-MeCTI}

$N$-Boc-iso-MeCTI was prepared using a synthetic strategy analogous to the route described for 3, beginning with the Stobbe condensation of the isomeric aldehyde 31 (Scheme 4). Compound $\mathbf{4 2}$ was resolved (Chiralcel OD, 5\% $i$-PrOH/hexane, $\alpha=1.44$ ), deprotected (25\% aqueous $\mathrm{HCO}_{2} \mathrm{NH}_{4}, 10 \% \mathrm{Pd} / \mathrm{C}, 60{ }^{\circ} \mathrm{C}, 2 \mathrm{~h}$ ) and the crude product was spirocyclized using DBU (10 equiv, DMF- $\mathrm{CH}_{3} \mathrm{CN}, 25^{\circ} \mathrm{C}, 4 \mathrm{~h}, 39 \%$ ) to give each enantiomer of 4 . Notably, the Ar-3' spirocyclization of this isomer was much slower and less facile than that of 3 .

\section{Synthesis of iso-MeCTI-TMI}

Deprotection of $42\left(4 \mathrm{~N} \mathrm{HCl}-\mathrm{EtOAc}, 25^{\circ} \mathrm{C}, 1 \mathrm{~h}\right)$ followed by coupling of the resulting hydrochloride salt with 5,6,7-trimethoxyindole-2-carboxylic acid (22,22 1.4 equiv, 4 equiv of EDCI, 3 equiv of $\mathrm{NaHCO}_{3}, 25^{\circ} \mathrm{C}, 15 \mathrm{~h}, 78 \%$ ) provided 44 . Hydrogenolysis of the benzyl ether ( $25 \%$ aqueous $\mathrm{HCO}_{2} \mathrm{NH}_{4}, 10 \% \mathrm{Pd} / \mathrm{C}, 60{ }^{\circ} \mathrm{C}, 2 \mathrm{~h}, 83 \%$ ) afforded $\mathbf{4 5}$. Spirocyclization of $\mathbf{4 5}$ was particularly slow (DBU/DMF) with this isomer such that hydrolysis of the labile amide was competitive. The use of an alternative solvent system $\left(2: 1 \mathrm{CH}_{3} \mathrm{CN} / \mathrm{DMF}\right)$ under strictly anhydrous conditions ( 6 equiv of DBU, $25{ }^{\circ} \mathrm{C}, 1 \mathrm{~h}, 71 \%$ ) gave 46 in improved conversions.

\section{Chemical Reactivity}

The relative reactivity of the alkylation subunits was established by measuring their rates of acid-catalyzed solvolysis. At $\mathrm{pH} 3\left(50 \% \mathrm{CH}_{3} \mathrm{OH}\right.$-buffer, buffer $=4: 1: 20 \mathrm{v} / \mathrm{v} / \mathrm{v} 0.1 \mathrm{M}$ citric acid, 0.2 $\mathrm{M} \mathrm{Na}_{2} \mathrm{HPO}_{4}, \mathrm{H}_{2} \mathrm{O}$ ), both $N$-Boc-MeCTI (3) and $N$-Boc-iso-MeCTI (4) underwent measurable solvolysis that was monitored spectrophotometrically by UV with the disappearance of the long wavelength absorption of the CTI chromophore and with the appearance of a short wavelength absorption attributable to the solvolysis product. The Boc derivatives of the two CTI isomers exhibited nearly indistinguishable reactivities $\left(t_{1 / 2}=206\right.$ and $209 \mathrm{~h}$ ), being ca. 5-6 fold more stable than the alkylation subunit of CC-1065 ( $\mathrm{N}$-BocMeCPI, $\left.t_{1 / 2}=37 \mathrm{~h}\right),{ }^{23}$ significantly more stable than $N$-Boc-CBI $\left(t_{1 / 2}=133 \mathrm{~h}\right),{ }^{24}$ and measurably more stable than even $N$-Boc-DSA $\left(t_{1 / 2}=177 \mathrm{~h}\right),{ }^{25}$ Figure 5 . This places $N$-BocMeCTI (3) and $N$-Boc-iso-MeCTI (4) among the most stable alkylation subunits explored to date that still exhibit a measurable reactivity at $\mathrm{pH} 3$. 


\section{Cytotoxic Activity}

The compounds displayed cytotoxic activity (L1210) consistent with their relative stabilities. Summarized in Figure 6 is the L1210 cytotoxic activity of the MeCTI and iso-MeCTI derivatives examined along with that of the key comparison compounds 26 and a full table of comparison derivatives is provided in the Supporting Information (Tables S1-S5). The natural enantiomers of $N$-Boc-MeCTI $\left(\mathrm{IC}_{50}=30 \mathrm{nM}\right)$ and $N$-Boc-iso-MeCTI $\left(\mathrm{IC}_{50}=25 \mathrm{nM}\right)$ proved to be ca. 10-fold more potent than the Boc derivative of the CC-1065 alkylation subunit $(\mathrm{N}$ Boc-MeCPI, IC $\left.\mathrm{I}_{50}=330 \mathrm{nM}\right),{ }^{23} 2-3$ fold more potent than $(+)-N$-Boc-CBI $\left(\mathrm{IC}_{50}=80 \mathrm{nM}\right)$, 24 but $4-5$ fold less potent than (+)- $N$-Boc-DSA $\left(\mathrm{IC}_{50}=6 \mathrm{nM}\right) .{ }^{25}$ With the exception of the latter comparison with (+)- $N$-Boc-DSA which exhibits an anomalously potent activity, the cytotoxic activity of $\mathbf{3}$ and $\mathbf{4}$ proved to be in line with expectations. The unnatural enantiomers of 3 and $4\left(\mathrm{IC}_{50}\right.$ 's $\left.=600 \mathrm{nM}\right)$ exhibited potencies 20 -fold less active than the natural enantiomers and in line with expectations based on the preceding observations with 5-7.

Similarly, the natural enantiomers of TMI derivatives 25 and $\mathbf{4 6}$ were found to be exceptionally potent cytotoxic agents $\left(\mathrm{IC}_{50}=5\right.$ and $7 \mathrm{pM}$, respectively), perhaps slightly more active than even (+)-duocarmycin SA ( $\left.\mathrm{IC}_{50}=8-10 \mathrm{pM}\right)^{25}$ and notably more potent than (+)-CBI-TMI $\left(\mathrm{IC}_{50}=30 \mathrm{pM}\right),{ }^{21}$ Figure $6 .{ }^{26}$ Their unnatural enantiomers, (ent-(-)-25 and ent-(-)-46), proved to be 100-300 fold less active than the natural enantiomers exhibiting a distinction between enantiomeric activities that is greater than that observed with duocarmycin SA (10fold $)^{25}$ or CBI-TMI (70-fold). ${ }^{21}$

Especially interesting is the comparison of $\mathrm{MeCTI}_{-\mathrm{PDE}_{2}}(\mathbf{8})$ with CC-1065 (1) and the synthetic hybrid natural product DSA-PDE $2(\mathbf{4 8}),{ }^{5 \mathrm{~d}_{\text {Figure }}} 7.26$ Consistent with expectations, the natural enantiomer of MeCTI-PDE $2\left(\mathrm{IC}_{50}=7 \mathrm{pM}\right)$ was found to be 3 -fold more potent than $\mathrm{CC}-1065\left(\mathrm{IC}_{50}=20 \mathrm{pM}\right)$ and nearly equipotent with DSA-PDE $2\left(\mathbf{4 8}, \mathrm{IC}_{50}=4 \mathrm{pM}\right)$. Thus, the deep-seated change of a single skeleton atom in $\mathrm{CC}-1065(\mathrm{NH} \rightarrow \mathrm{S})$ served to increase its potency 3 -fold in line with expectations based on its 5-6 fold increased stability.

In a series of indole 2 analogues that are more manageable to work with because of their improved physical properties including their solubility in conventional organic solvents and which have exhibited efficacious in vivo antitumor activity, 10,27 the MeCTI derivative 30 exhibited a cytotoxic potency precisely in line with expectations based on its enhanced stability, Figure $8{ }^{26}$ Thus, the natural enantiomer of MeCTI-indole 2 (30) was found to be ca. 8-fold more potent than MeCPI-indole 2 (49) ${ }^{10,28}$ in line with its 5-6 fold increased stability, 2-fold more potent than CBI-indole 27 consistent with its 1.5 -fold increased stability, and ca. 2-fold less potent than DSA-indole 2 (1.2-fold difference in reactivity). Similarly, the unnatural enantiomer of MeCTI-indole $2\left(\mathrm{IC}_{50}=250 \mathrm{pM}\right)$ proved to be 50 -fold less active than the natural enantiomer, but similarly 4-fold more potent than MeCPI-indole $2\left(\mathrm{IC}_{50}=1000 \mathrm{pM}\right)$ and essentially equipotent with DSA-indole $2\left(\mathrm{IC}_{50}=150 \mathrm{pM}\right)$.

\section{The Parabolic Relationship}

Among the most important of the features established to date with this class of compounds is the relationship between chemical stability and biological potency (cytotoxic activity). This parabolic relationship extends over a $10^{6}$-fold range in reactivities $(-\log k, \mathrm{pH} 3)$ and activities $\left(-\log \mathrm{IC}_{50}, \mathrm{~L} 1210\right)$ covering an extensive range of modified alkylation subunits. Consistent with the design features, $N$-Boc-MeCTI ( $\mathrm{pH} 3$ solvolysis $t_{1 / 2}=206 \mathrm{~h}$ ) as well as $N$-Boc-isoMeCTI (pH 3 solvolysis $\left.t_{1 / 2}=209 \mathrm{~h}\right)$ exhibit a reactivity comparable to $N$-Boc-DSA $\left(t_{1 / 2}=\right.$ $177 \mathrm{~h}$ ) that lies at the pinnacle of the parabolic relationship at a point that is 5-6 times more stable than $N$-Boc-MeCPI. In line with this enhanced stability, the Boc derivatives of both CTI isomers exhibit a cytotoxic activity roughly 10 -fold more potent than $N$-Boc-MeCPI $\left(\mathrm{IC}_{50}=\right.$ $330 \mathrm{nM})$ and $4-5$ fold less potent than $N$-Boc-DSA $\left(\mathrm{IC}_{50}=6 \mathrm{nM}\right)$ placing them near 
expectations based on the parabolic relationship (Figure 9). ${ }^{26}$ Importantly and aside from the anomalously potent activity of $N$-Boc-DSA, this places both MeCTI derivatives among the most potent analogues examined to date on par with the activity of $N$-Boc-CCBI further defining the pinnacle of the parabolic relationship.

\section{DNA Alkylation Selectivity and Efficiency}

The DNA alkylation selectivity of the new analogues were examined within a 150 base-pair segment of DNA described previously (w794). 30 The alkylation site identification and the assessment of the relative selectivity among the available sites were obtained by thermallyinduced strand cleavage of the singly 5'-end-labeled duplex DNA after exposure to the compounds as detailed. ${ }^{5-8}$ Since the DNA alkylation properties of members of each class of these agents have been established in preceding studies, we focused our analysis on a select set of the new analogues to simply confirm their DNA alkylation selectivity and relative efficiency. Most representative of this set are the TMI and PDE-based analogues constituting key analogues of duocarmycin SA and CC-1065, respectively.

Illustrated in Figure 10 is a representative comparison of the DNA alkylation selectivity of the TMI-based analogues which highlights the similarity as well as subtle distinctions in the compounds. As anticipated, the TMI-based analogues 25 and $\mathbf{4 6}$ exhibited a DNA alkylation selectivity identical to all such TMI derivatives including duocarmycin SA itself. Within this segment of DNA, the natural and unnatural enantiomers each alkylate a single major site and the only significant distinction detected was their relative efficiencies of DNA alkylation. In each case, the natural enantiomer alkylates DNA with a greater efficiency than the corresponding unnatural enantiomer. Throughout both enantiomeric series, duocarmycin SA, MeCTI-TMI, and iso-MeCTI-TMI exhibited no distinction in their relative efficiencies of DNA alkylation, whereas CBI-TMI (CBI-TMI $<$ MeCPI-TMI) ${ }^{21}$ was less effective.

In a subtle contrast to this behavior, the $\mathrm{PDE}_{2}$ derivatives illustrated in Figure 11 alkylated the same major sites in both enantiomeric series with DSA-PDE 2 and $\mathrm{MeCTI}_{2} \mathrm{PDE}_{2}$ exhibiting an efficiency that subtly exceeds that of (+)-CC-1065. Most significant in this series and consistent with their relative cytotoxic potencies, the unnatural enantiomers now approach or match the DNA alkylation efficiencies of the natural enantiomers.

To date, the biological properties of members of this class of natural products have typically mirrored their relative efficiencies of DNA alkylation. As illustrated in the preceding section, the observations illustrated in Figure 10 and 11 mirror the cytotoxic activities observed within the series and even between enantiomeric pairs of such analogues.

\section{In Vivo Antitumor Activity}

The natural enantiomer of CTI-indole 2 (30) was examined for in vivo efficacy in a standard antitumor model enlisting L1210 murine leukemia implanted i.p. into DBA/2J mice. This model has been shown to respond well to related compounds 31 and is a system that collaborators through the years have used to assess an extensive series of (+)-CBI-indole 2 analogues. ${ }^{27}$ Although not published, these latter studies provided the foundation on which we based our examination of $\mathbf{3 0}$. Thus, (+)-30 was examined with the dose range (10-100 1g/ $\mathrm{kg}$ ) and the dosing schedule (administered three times i.p. on days 1, 5, and 9) found suitable for related agents including (+)-CBI-indole 27 (Figure 12). Although the higher doses (100 and $601 \mathrm{~g} / \mathrm{kg}$ ) were found to be toxic to the treated animals, efficacious antitumor activity was observed at the lower doses producing 4/6 (at $101 \mathrm{~g} / \mathrm{kg}$ ) and 3/6 (at $301 \mathrm{~g} / \mathrm{kg}$ ) long term survivors (>80 days) in the experiment. This efficacy is at least as good as and may exceed that observed with related drugs in this class in this tumor model, and occurs at an optimal dose that is lower than that observed with (+)-CBI-indole $2(30-601 \mathrm{~g} / \mathrm{kg})$ or related MeCPI-based 
agents. Thus, the enhanced chemical stability of the alkylation subunit leads to a greater in vivo potency and a maintained or further enhanced efficacy.

\section{Conclusions}

The MeCTI alkylation subunit was designed based on the fundamental relationship between reactivity and biological potency observed in this class of DNA alkylating agents. The $\mathrm{pH} 3$ solvolysis reactivity of MeCPI $\left(t_{1 / 2}=37 \mathrm{~h}\right)$ found in the natural product CC-1065 is more reactive than the optimal naturally occurring alkylation subunit DSA $\left(t_{1 / 2}=177 \mathrm{~h}\right)$. Computational studies (AM1, MNDO) predicted that a single atom change in the MeCPI alkylation subunit ( $\mathrm{S}, \mathrm{MeCTI}$ vs $\mathrm{NH}, \mathrm{MeCPI}$ ) would impart an increased stability that was expected to increase the biological potency of the alkylation subunit approaching that of DSA.

The alkylation subunit MeCTI and its isomer iso-MeCTI were prepared and found to be slightly more stable than DSA ( $\mathrm{pH} 3$ solvolysis: MeCTI, $t_{1 / 2}=206 \mathrm{~h}$; iso-MeCTI, $t_{1 / 2}=209 \mathrm{~h}$ ) placing it at the point representing an optimal balance between chemical reactivity and stability based on the established parabolic relationship. Consistent with their increased relative stabilities, the natural enantiomers of $N$-Boc-MeCTI $\left(\mathrm{IC}_{50}=20 \mathrm{nM}\right)$ and $N$-Boc-iso-MeCTI $\left(\mathrm{IC}_{50}=25\right.$ $\mathrm{nM}$ ) proved to be 10 -fold more potent than the CC-1065 alkylation subunit (+)- $\mathrm{N}$-Boc-MeCPI $\left(\mathrm{IC}_{50}=330 \mathrm{nM}\right), 2-3$ fold more potent than $(+)-N$-Boc-MeCBI $\left(\mathrm{IC}_{50}=80 \mathrm{nM}\right)$, but $4-5$ fold less potent than the anomalously potent (+)- $N$-Boc-DSA. The unnatural enantiomers of $N$-BocMeCTI and $N$-Boc-iso-MeCTI $\left(\mathrm{IC}_{50}=600 \mathrm{nM}\right)$ each exhibited potencies 20 -fold less active than the natural enantiomers and consistent with expectations for this class of agents.

Key natural product analogues evaluated included (+)-MeCTI-TMI (5 pM) and its isomer (+)iso-MeCTI (7 pM) which matched or slightly exceeded the potency of duocarmycin SA (DSATMI, 8-10 pM), a natural product incorporating the optimal naturally occurring alkylation subunit. Also prepared and evaluated was a key MeCTI analogue of CC-1065. The analogue $8\left(\mathrm{MeCTI}_{-} \mathrm{PDE}_{2}\right)$ constitutes the substitution of a single atom in the alkylation subunit of CC-1065, providing a compound that exhibited an identical DNA alkylation profile relative to CC-1065 $\left(\mathrm{IC}_{50}=20 \mathrm{pM}\right)$, but is 3 -fold more potent $\left(\mathrm{IC}_{50}=7 \mathrm{pM}\right.$, natural enantiomer $)$ than the natural product. Additionally consistent with expectations based on their similar inherent reactivities, MeCTI-PDE 2 was also comparable in potency with DSA-PDE $2\left(\mathrm{IC}_{50}=4 \mathrm{pM}\right)$. Extending these observations, the incorporation of $\mathrm{MeCTI}$ into an indole 2 derivative and its comparison with an important series of alkylation subunit derivatives further verified the direct impact of the relative reactivities on the cytotoxic potency. These observations and a subsequent demonstration of its in vivo antitumor potency and efficacy places (+)-MeCTIindole $_{2}$ among the most interesting such derivatives disclosed to date.

Most importantly, these observations are derived from and in line with expectations based on the extensive examination of a series of alkylation subunit analogues that defined a direct relationship between chemical stability and biological potency characteristic of this class of antitumor agents. Presumably, the underlying parabolic relationship reflects the fact that the compounds must be sufficiently stable to reach their biological target, yet reactive enough to effectively alkylate DNA once it does. ${ }^{26}$

\section{Supplementary Material}

Refer to Web version on PubMed Central for supplementary material. 


\section{Acknowledgements}

We gratefully acknowledge the financial support of the National Institutes of Health (CA41986 and CA42056), the Skaggs Institute for Chemical Biology, and predoctoral fellowship support from the American Chemical Society (2005-2006 M.S.T., sponsored by Roche Pharmaceuticals). K.S.M. and M.S.T. are Skaggs Fellows.

\section{References}

1. CC-1065: Martin DG, Biles C, Gerpheide SA, Hanka LJ, Krueger WC, McGovren JP, Mizsak SA, Neil GL, Stewart JC, Visser J. J Antibiot 1981;34:1119-1125. [PubMed: 7328053]

2. Duocarmycin SA, Ichimura M, Ogawa T, Takahashi K, Kobayashi E, Kawamoto I, Yasuzawa T, Takahashi I, Nakano H. J Antibiot 1990;43:1037-1038. [PubMed: 2211354]

3. Duocarmycin A, Takahashi I, Takahashi K, Ichimura M, Morimoto M, Asano K, Kawamoto I, Tomita F, Nakano H. J Antibiot 1988;41:1915-1917. [PubMed: 3209484]

4. Yatakemycin: Igarashi Y, Futamata K, Fujita T, Sekine A, Senda H, Naoki H, Furumai T. J Antibiot 2003;56:107-113. [PubMed: 12715869]

5. Yatakemycin: (a) Parrish JP, Kastrinsky DB, Wolkenberg SE, Igarashi Y, Boger DL. J Am Chem Soc 2003;125:10971-10976. [PubMed: 12952479] (b) Trzupek JD, Gottesfeld JM, Boger DL. Nature Chem Biol 2006;2:79-82. [PubMed: 16415862] (c) Tichenor MS, Trzupek JD, Kastrinsky DB, Shiga F, Hwang I, Boger DL. J Am Chem Soc 2006;128:15683-15696. [PubMed: 17147378] (d) Tichenor MS, MacMillan KS, Trzupek JD, Rayl TJ, Hwang I, Boger DL. J Am Chem Soc 2007;129:1085810869. [PubMed: 17691783]

6. (a) CC-1065: Hurley LH, Lee C-S, McGovren JP, Warpehoski MA, Mitchell MA, Kelly RC, Aristoff PA. Biochemistry 1988;27:3886-3892. [PubMed: 3408734] (b) Hurley LH, Warpehoski MA, Lee CS, McGovren JP, Scahill TA, Kelly RC, Mitchell MA, Wicnienski NA, Gebhard I, Johnson PD, Bradford VS. J Am Chem Soc 1990;112:4633-4649. (c) Boger DL, Johnson DS, Yun W, Tarby CM. Bioorg Med Chem 1994;2:115-135. [PubMed: 7922122] (d) Boger DL, Coleman RS, Invergo BJ, Sakya SM, Ishizaki T, Munk SA, Zarrinmayeh H, Kitos PA, Thompson SC. J Am Chem Soc 1990;112:46234632.

7. Duocarmycin A: (a) Boger DL, Ishizaki T, Zarrinmayeh H, Munk SA, Kitos PA, Suntornwat O. J Am Chem Soc 1990;112:8961-8971. (b) Boger DL, Ishizaki T, Zarrimayeh H. J Am Chem Soc 1991;113:6645-6649. (c) Boger DL, Yun W, Terashima S, Fukuda Y, Nakatani K, Kitos PA, Jin Q. Bioorg Med Chem Lett 1992;2:759-765.

8. Duocarmycin SA, Boger DL, Johnson DS, Yun W. J Am Chem Soc 1994;116:1635-1656.

9. Reviews: (a) Boger DL, Johnson DS. Angew Chem Int Ed Engl 1996;35:1438-1474. (b) Boger DL. Acc Chem Res 1995;28:20-29. (c) Boger DL, Johnson DS. Proc Natl Acad Sci USA 1995;92:36423649. [PubMed: 7731958] (d) Boger DL, Garbaccio RM. Acc Chem Res 1999;32:1043-1052.

10. Warpehoski MA, Gebhard I, Kelly RC, Krueger WC, Li L, McGovern JP, Praire MD, Wienienski N, Wierenga W. J Med Chem 1988;31:590-603. [PubMed: 3346875]

11. (a) Boger DL, Coleman RS, Invergo BJ, Zarrinmayeh H, Kitos PA, Thompson SC, Leong T, McLaughlin LW. Chem-Biol Interact 1990;73:29-52. [PubMed: 2406033] (b) Boger DL, Zarrinmayeh H, Munk SA, Kitos PA, Suntornwat O. Proc Natl Acad Sci USA 1991;88:1431-1435. [PubMed: 1847523] (c) Boger DL, Munk SA, Zarrinmayeh H. J Am Chem Soc 1991;113:3980 3983. (d) Boger DL, Johnson DS. J Am Chem Soc 1995;117:1443-1444.

12. Boger DL, Bollinger B, Hertzog DL, Johnson DS, Cai H, Mesini P, Garbaccio RM, Jin Q, Kitos PA. J Am Chem Soc 1997;119:4987-4998.

13. Boger DL, Garbaccio RM. Bioorg Med Chem 1997;5:263-276. [PubMed: 9061191]

14. Reviews: (a) Wolkenberg SE, Boger DL. Chem Rev 2002;102:2477-2496. [PubMed: 12105933] (b) Tse WC, Boger DL. Chem Biol 2004;11:1607-1617. [PubMed: 15610844]

15. (a) Boger DL, Ishizaki T. Tetrahedron Lett 1990;31:793-796. (b) Boger DL, Munk SA, Ishizaki T. J Am Chem Soc 1991;113:2779-2780. (c) Boger DL, Yun W. J Am Chem Soc 1994;116:5523-5524.

16. (a) Parrish JP, Hughes TV, Hwang I, Boger DL. J Am Chem Soc 2004;126:80-81. [PubMed: 14709069] (b) Parrish JP, Trzupek JD, Hughes TV, Hwang I, Boger DL. Bioorg Med Chem 2004;12:5845-5856. [PubMed: 15498660] 
17. (a) Muratake H, Hayakawa A, Natsume M. Chem Pharm Bull 2000;48:1558-1566. [PubMed: 11045469] (b) Muratake H, Okabe K, Takahashi M, Tonegawa M, Natsume M. Chem Pharm Bull 1997;45:799-806. (c) Muratake H, Hayakawa A, Natsume M. Tetrahedron Lett 1997;38:7577-7580.

18. (a) Boger DL, McKie JA, Cai H, Cacciari B, Baraldi PG. J Org Chem 1996;61:1710-1729. [PubMed: 11667041] (b) Boger DL, Han N, Tarby CM, Boyce CW, Cai H, Jin Q, Kitos PA. J Org Chem 1996;61:4894-4912. (c) Review of related efforts: Boger DL, Boyce CW, Garbaccio RM, Goldberg JA. Chem Rev 1997;97:787-828. [PubMed: 11848889]

19. Boger DL, McKie JA. J Org Chem 1995;60:1271-1275.

20. (a) Boger DL, Boyce CW, Garbaccio RM, Searcey M. Tetrahedron Lett 1998;39:2227-2230. (b) Patel VF, Andis SL, Enkema JK, Johnson DA, Kennedy JH, Mohamadi F, Schultz RM, Soose DJ, Spees MM. J Org Chem 1997;62:8868-8874.

21. Boger DL, Yun W. J Am Chem Soc 1994;116:7996-8006.

22. Boger DL, Ishizaki T, Zarrinmayeh H, Kitos PA, Suntornwat O. J Org Chem 1990;55:4499-4502.

23. (a) Boger DL, Coleman RS. J Am Chem Soc 1987;109:2717-2727. (b) Coleman DLRS. J Am Chem Soc 1988;110:1321-1323. 4796-4807.

24. (a) Boger DL, Ishizaki T, Wysocki RJ Jr, Munk SA, Kitos PA, Suntornwat O. J Am Chem Soc 1989;111:6461-6463. (b) Boger DL, Ishizaki T, Kitos PA, Suntornwat O. J Org Chem 1990;55:58235832 .

25. (a) Boger DL, Machiya K. J Am Chem Soc 1992;114:10056-10058. (b) Boger DL, Machiya K, Hertzog DL, Kitos PA, Holmes D. J Am Chem Soc 1993;115:9025-9036.

26. The L1210 cytotoxic activity for (+)-ducarmycin SA (8-10 pM) and (+)-CC-1065 (20 pM; 23-18 pM) have been tested as standards ( $>100$ times) through the years and side-by-side with the samples disclosed herein. The small 2-3 fold differences are always observed and the absolute potencies always fall in this narrow range indicated $( \pm 20 \%)$. We have developed highly refined, reproducible conditions for conducting such cytotoxic assays $( \pm 20 \%)$ that avoid the more variable results typically experienced with such assays. The $\mathrm{IC}_{50}$ 's reported in Figures $6-8$ are the average values $( \pm 20 \%)$ obtained typically from multiple rounds of testing and the number of times the samples disclosed

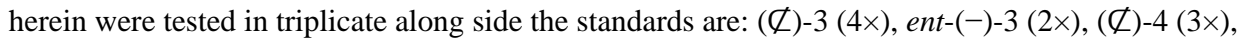

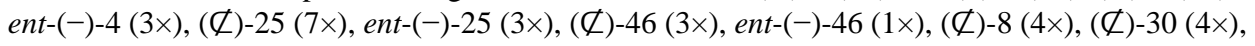
and ent-(-)-30 (3x).

27. (a) Boger DL, Ishizaki T, Sakya SM, Munk SA, Kitos PA, Jin Q, Besterman JM. Bioorg Med Chem Lett 1991;1:115-120. (b) Boger DL, Yun W, Han N. Bioorg Med Chem 1995;3:1429-1453. [PubMed: 8634824]

28. Aristoff PA, Johnson PD, Sun D. J Med Chem 1993;36:1956-1963. [PubMed: 8336335]

29. Boger DL, Hertzog DL, Bollinger B, Johnson DS, Cai H, Goldberg J, Turnbull P. J Am Chem Soc 1997;119:4977-4986.

30. Boger DL, Munk SA, Zarrinmayeh H, Ishizaki T, Haught J, Bina M. Tetrahedron 1991;47:26612682.

31. Li LH, Kelly RC, Warpehoski MA, McGovren JP, Gebhard I, DeKoning TF. Invest New Drugs 1991;9:137-150. [PubMed: 1874598] 
<smiles></smiles><smiles>CC=C(C)C(C)OC(=O)C(C)C(C)C</smiles><smiles>COc1cc2cc(C(=O)N3CC4CC45C3=CC(=O)C(N)=C5C)[nH]c2c(OC)c1OC</smiles>

Figure 1.

Natural Products. 


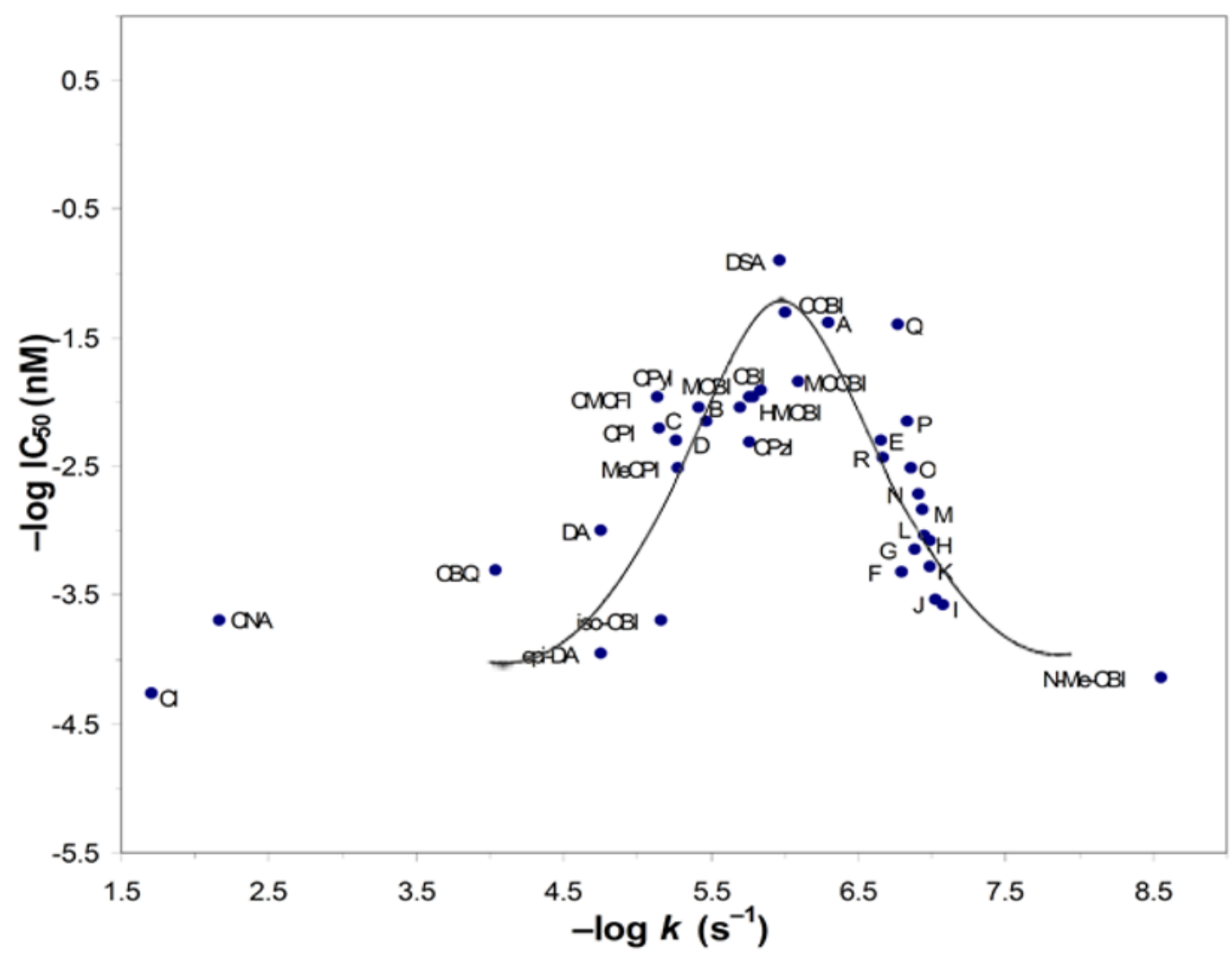

Figure 2.

Relationship between reactvity (solvolysis $-\log k, \mathrm{pH} 3)$ and cytotoxic potency $\left(-\log \mathrm{IC}_{50}\right.$, L1210), natural enantiomers. See Supporting Information for abbreviations and key to letter notations. 
<smiles>Cc1csc2c1C13CC1CN(C(=O)OC(C)(C)C)C(=CC2=O)C3=O</smiles>

$\mathrm{O}$<smiles>Cc1cc2c(s1)C13CC1CN(C(C)(C)C)C3=CC2=O</smiles>

4, N-Boc-iso-MeCTI<smiles>O=C1C=C2C([N+](=O)[O-])CC3CC23c2ccccc21</smiles>

6, N-Boc-CBI<smiles>Cc1c[nH]c2c1C13CC1CN(C(C)(C)C)C3=CC2=O</smiles>

5, N-Boc-MeCPI<smiles>COC(=O)c1cc2c([nH]1)C(=O)C=C1C3CN(C(=O)O)C12C3</smiles>

7, N-Boc-DSA<smiles>COC(=O)N1CC2CC23C2=CC(=O)c4scc(C)c4C23C1</smiles><smiles>COC(=O)N1CC(C)c2c1cc(O)c1scc(C)c21</smiles>

\begin{tabular}{llll} 
Agent & Spiro & Product & $\Delta \Delta H(\mathrm{kcal})$ \\
\hline $\mathrm{Cl}$ & -22.92 & -81.28 & -58.36 \\
$\mathrm{MeCPI}$ & -15.62 & -66.31 & -50.69 \\
$\mathrm{CBI}$ & -22.68 & -62.99 & -40.31 \\
$\mathrm{MeCTI}$ & -24.91 & -63.40 & -38.49
\end{tabular}

Figure 3.

Alkylation subunits and AM1 calculated heats of reaction for hydride addition to the activated cyclopropane. 
Single atom substitution to enhance potency?

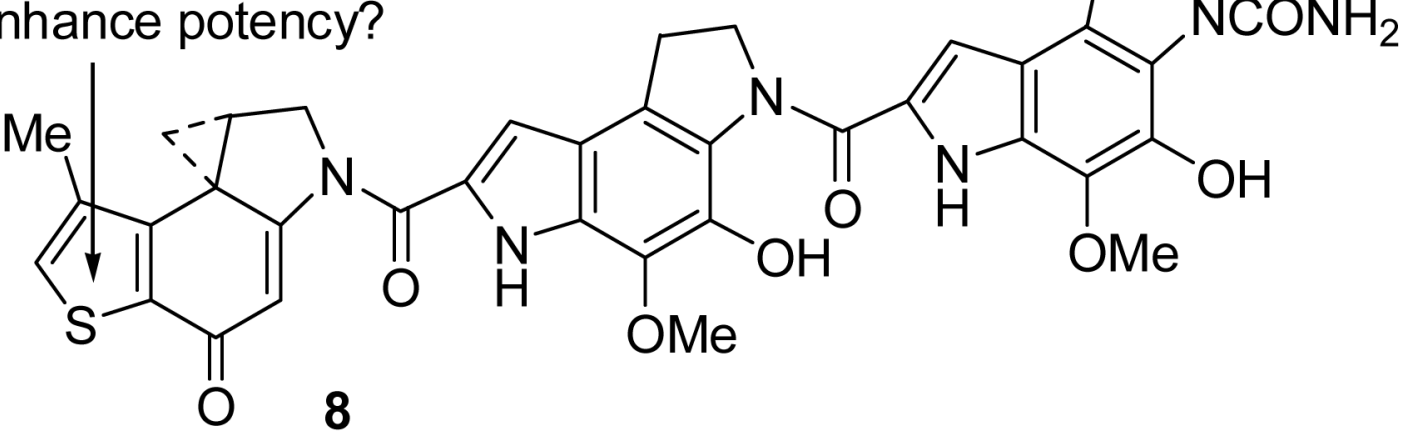

Figure 4.

Structure of (+)-MeCTI-PDE 2 . 
<smiles>Cc1csc2c1C13CC1CN(C(C)(C)C)C3=CC2=O</smiles><smiles></smiles><smiles>Cc1c[nH]c2c1C13CC1CN(C(C)(C)C)C3=CC2=O</smiles>

3

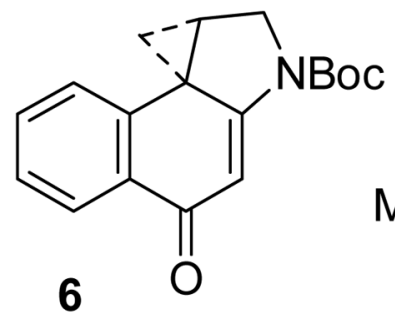<smiles>[3H]C(=O)OC(C)(C)OC(=O)C1=CC(=O)c2[nH]c(C(=O)OC)cc2C12CC2C</smiles>
C

$\begin{array}{llr}\text { 3, N-Boc-CTI } & 9.30 \times 10^{-7} & 206 \\ \text { 4, N-Boc-iso-CTI } & 9.20 \times 10^{-7} & 209 \\ \text { 5, N-Boc-MeCPI } & 5.26 \times 10^{-6} & 37 \\ \text { 6, N-Boc-CBI } & 1.45 \times 10^{-6} & 133 \\ \text { 7, N-Boc-DSA } & 1.08 \times 10^{-6} & 177\end{array}$

Figure 5.

Solvolysis Reactivity. 


\begin{tabular}{lrr} 
& \multicolumn{2}{c}{$\mathrm{L} 1210 \mathrm{IC}_{50}, \mathrm{nM}$} \\
\cline { 2 - 3 } Compound & nat & unnat \\
\hline 3, N-Boc-MeCTI & 30 & 600 \\
4, N-Boc-iso-MeCTI & 25 & 600 \\
$\mathbf{5}$, N-Boc-MeCPI & 330 & nd \\
6, N-Boc-CBI & 80 & 900 \\
7, N-Boc-DSA & 6 & 60 \\
& & \\
25, MeCTI-TMI & 0.005 & 2 \\
46, iso-MeCTI-TMI & 0.007 & 0.8 \\
47, CBI-TMI & 0.030 & 2 \\
2, duocarmycin SA & 0.008 & 0.10
\end{tabular}

Figure 6.

Cytotoxic Activity. 26 


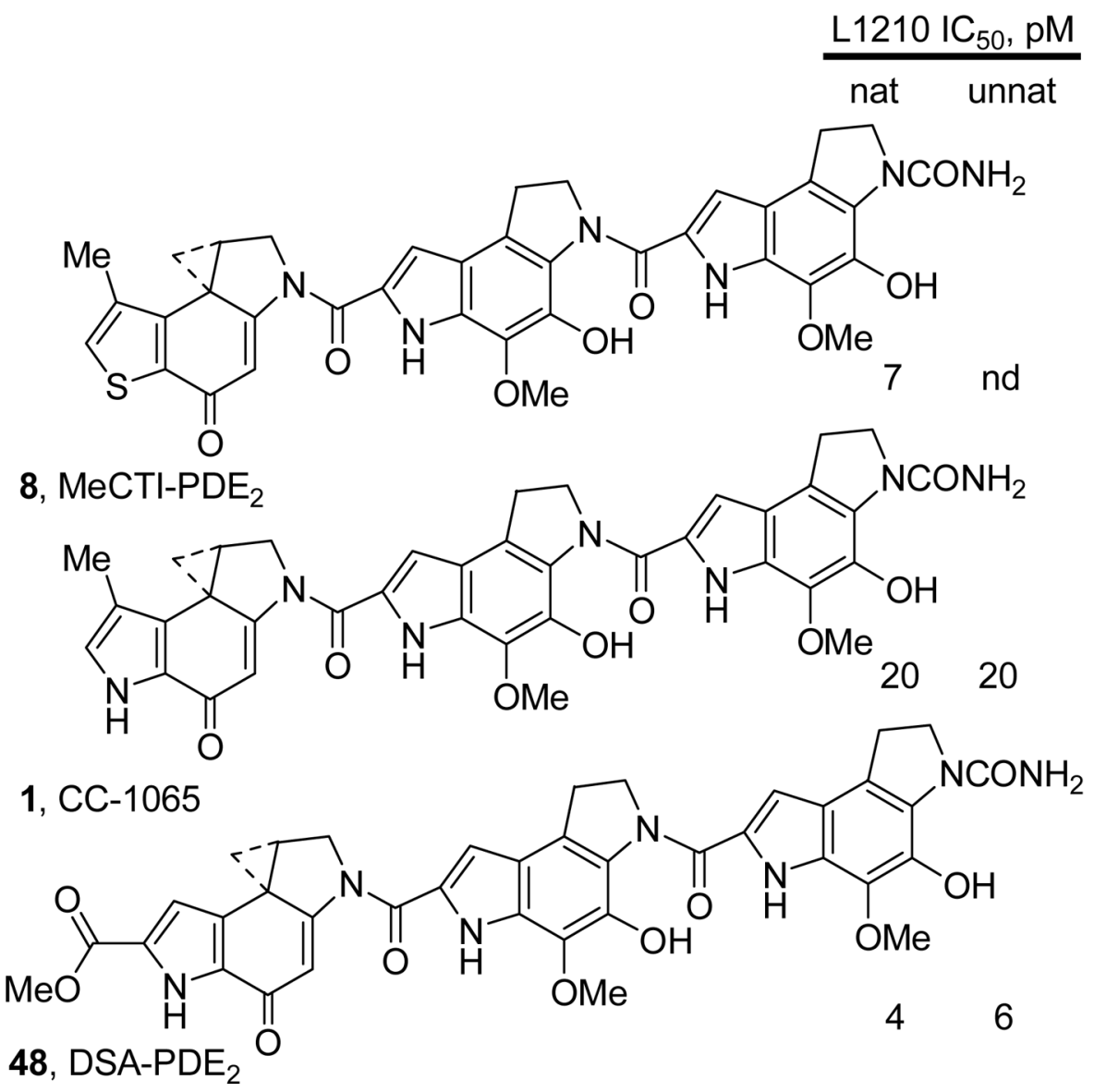

Figure 7.

Cytotoxic activity of $\mathrm{PDE}_{2}$ derivatives. 26 


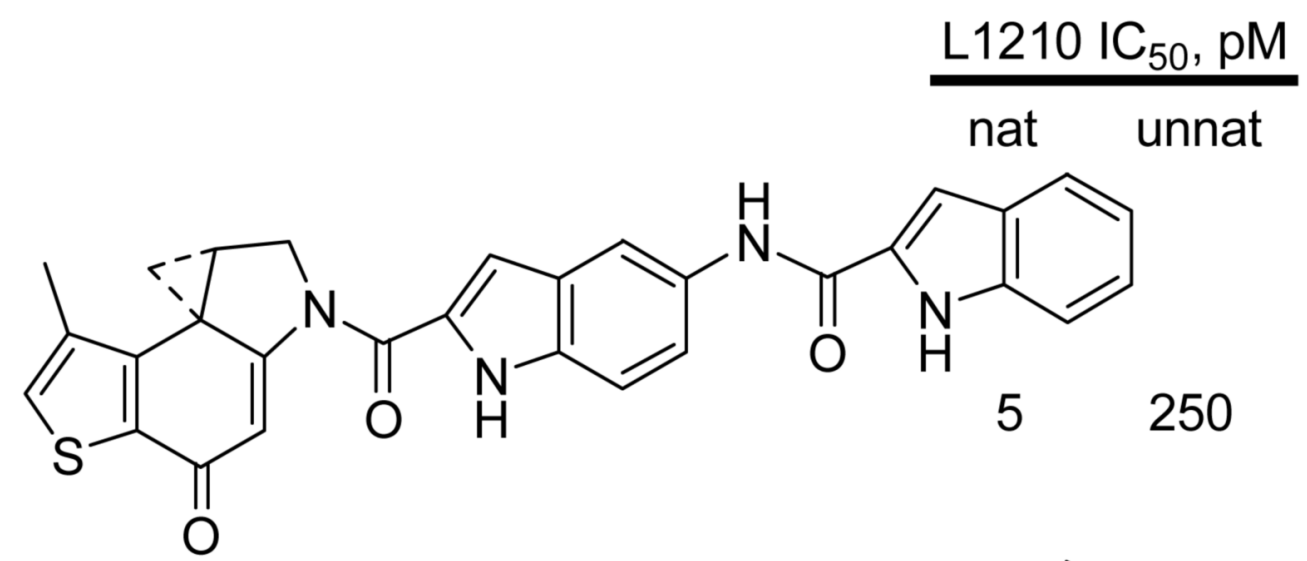

30, MeCTI-indole 2<smiles>Cc1c[nH]c2c1C13CC1CNC3=CC2=O</smiles><smiles>NC(=O)c1cc2cc(NC(=O)c3cc4ccccc4[nH]3)ccc2[nH]1</smiles>

49, CPI-indole 2<smiles>COC(=O)c1cc2c([nH]1)C(=O)C=C1N(C(=O)c3cc4cc(F)ccc4[nH]3)CC3[C@H](C=[CoH])C123</smiles><smiles>CNC(=O)c1cc2ccccc2[nH]1</smiles>

50, DSA-indole 2<smiles>O=C(Nc1ccc2[nH]c(C(=O)N3CC4CC45C3=CC(=O)c3ccccc35)cc2c1)c1cc2ccccc2[nH]1</smiles>

51, $\mathrm{CBI}$-indole 2

Figure 8.

Cytotoxic activity of indole 2 derivatives. ${ }^{26}$ 


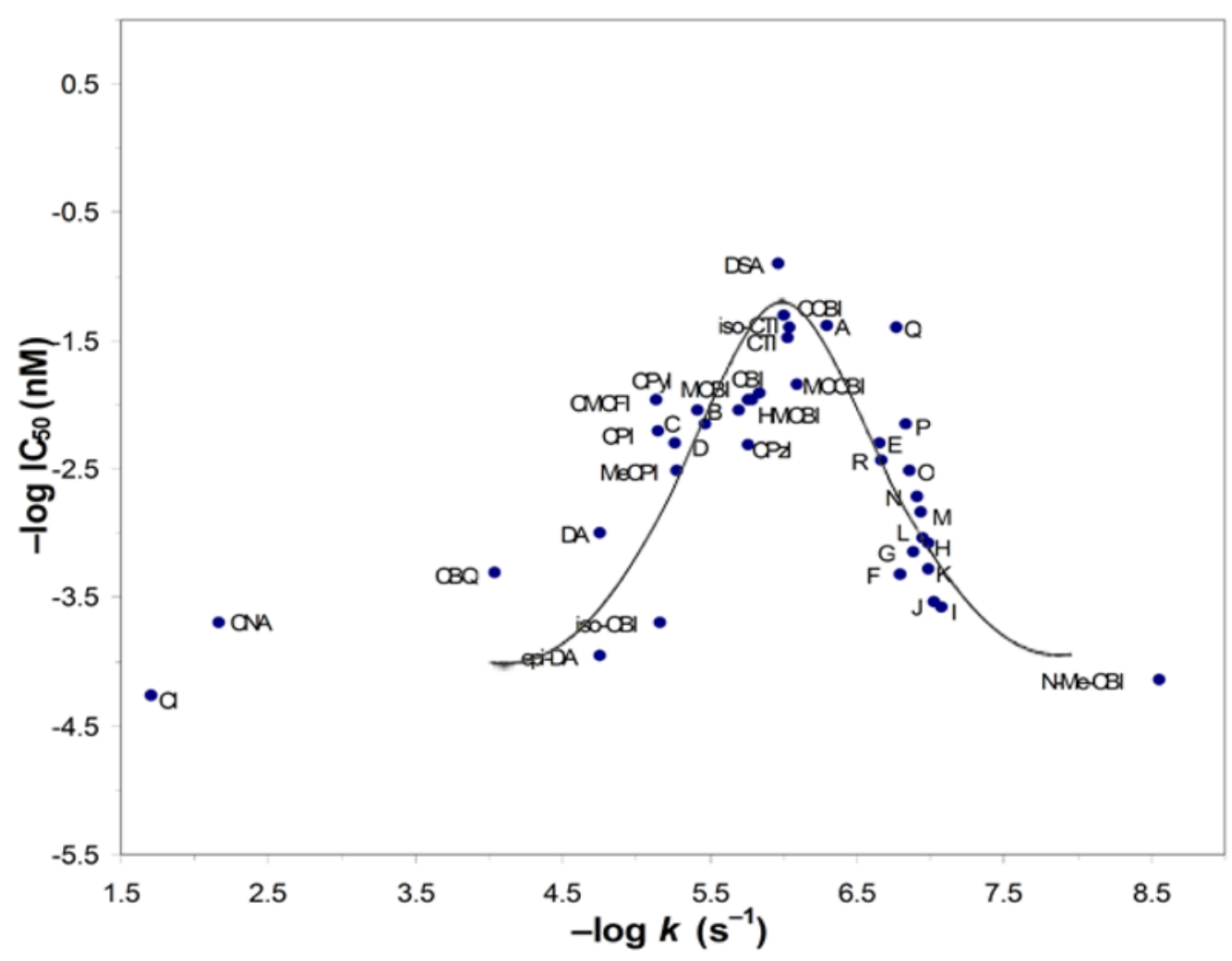

Figure 9.

Relationship between reactivity (solvolysis $k, \mathrm{pH} 3$ ) and cytotoxic potency (L1210), natural enantiomers. 


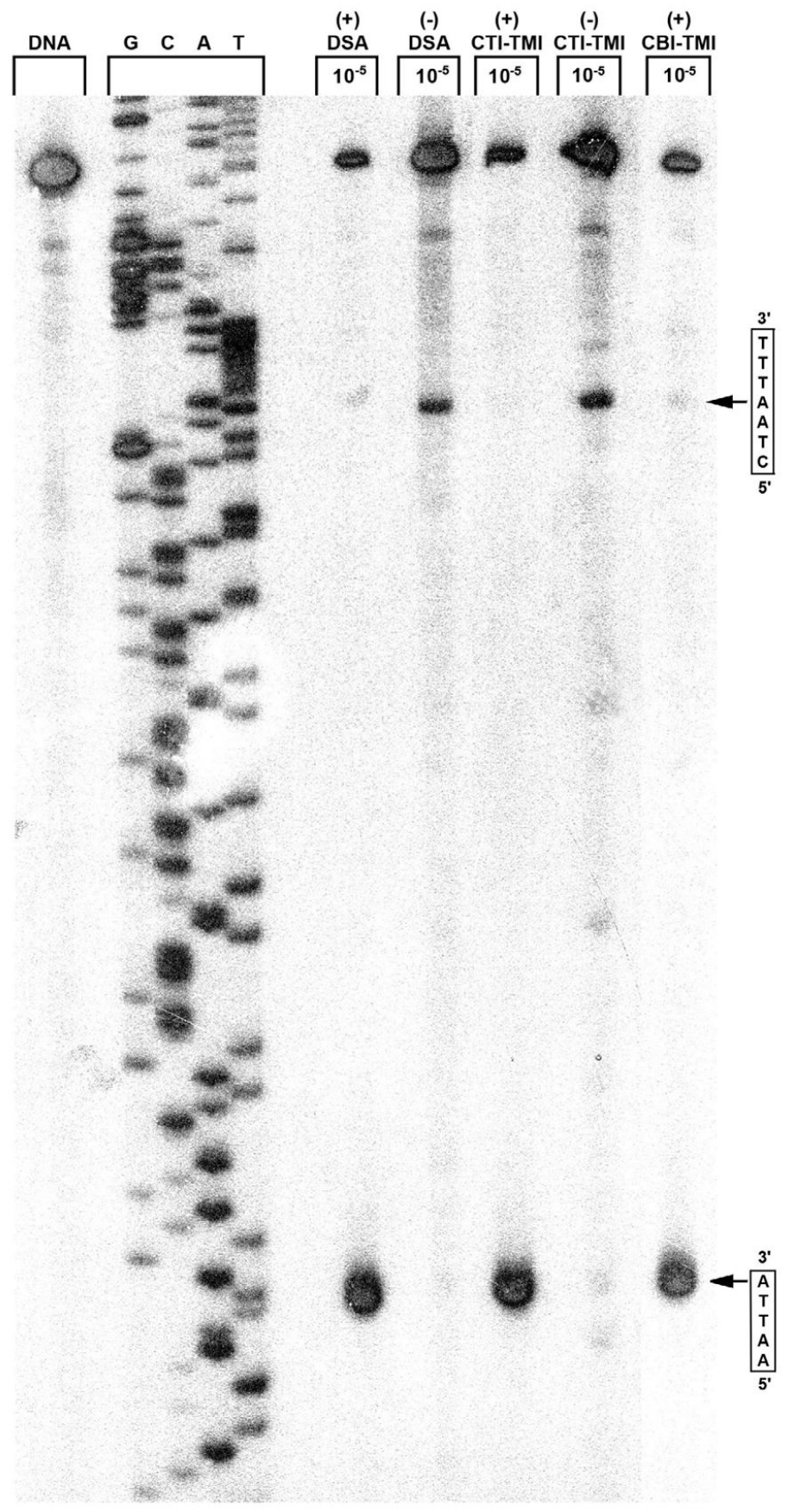

Figure 10.

Thermally-induced strand cleavage of w794 DNA (144 bp, nucleotide no. 5238-138) after DNA-agent incubation with duocarmycin SA, MeCTI-TMI, and CBI-TMI $\left(20^{\circ} \mathrm{C}, 24 \mathrm{~h}\right)$, removal of unbound agent by $\mathrm{EtOH}$ precipitation and $30 \mathrm{~min}$ thermolysis $\left(100{ }^{\circ} \mathrm{C}\right)$, followed by denaturing $8 \%$ PAGE and autoradiography. Lane 1, control DNA; lanes 2-5, Sanger G, C, $\mathrm{A}$, and T sequencing standards; lanes 6 and 7, (+)-duocarmycin SA and ent-(-)-duocarmycin SA $\left(1 \times 10^{-5} \mathrm{M}\right)$; lanes 8 and 9, (+)-MeCTI-TMI and ent-(-)-MeCTI-TMI $\left(1 \times 10^{-5} \mathrm{M}\right)$; lane 10, (+)-CBI-TMI $\left(1 \times 10^{-5} \mathrm{M}\right)$. 


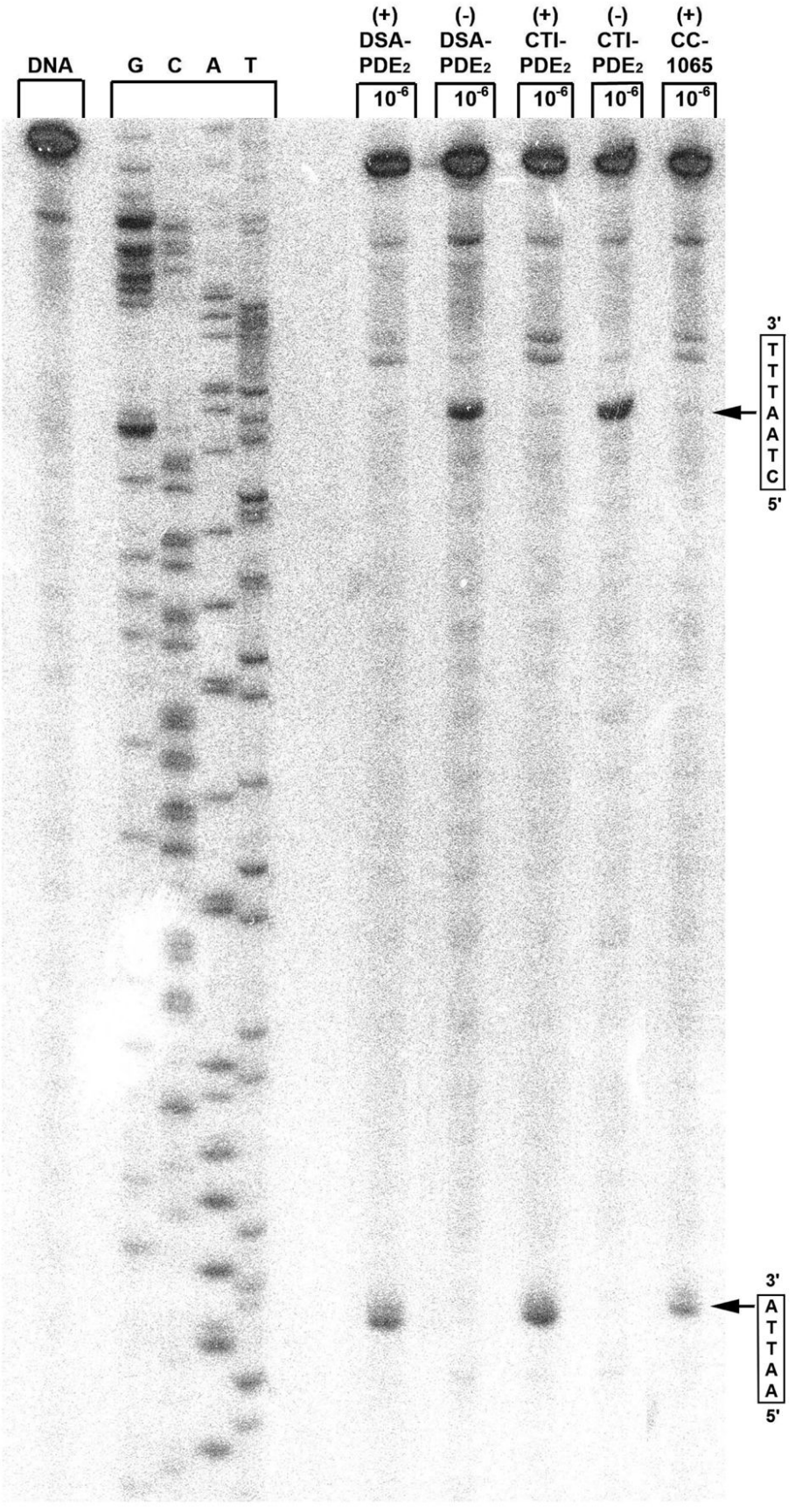

Figure 11.

Thermally-induced strand cleavage of w794 DNA (144 bp, nucleotide no. 5238-138) after DNA-agent incubation with DSA-PDE-PDE $\left(23^{\circ} \mathrm{C}, 24 \mathrm{~h}\right), \operatorname{MeCTI}-P D E-P D E ~\left(23{ }^{\circ} \mathrm{C}, 24 \mathrm{~h}\right)$, and $\mathrm{CC}-1065\left(23^{\circ} \mathrm{C}, 24 \mathrm{~h}\right)$, removal of unbound agent by EtOH precipitation and $30 \mathrm{~min}$. thermolysis $\left(100^{\circ} \mathrm{C}\right)$, followed by denaturing $8 \%$ PAGE and autoradiography. Lane 1, control DNA; lanes 2-5, Sanger G, C, A, and T sequencing standards; lane 6, (+)-DSA-PDE-PDE $\left(1 \times 10^{-6} \mathrm{M}\right)$; lane 7 , ent-(-)-DSA-PDE-PDE $\left(1 \times 10^{-6} \mathrm{M}\right)$; lane 8 , (+)-MeCTI-PDE-PDE $\left(1 \times 10^{-6} \mathrm{M}\right)$; lane 9, ent-(-)-MeCTI-PDE-PDE $\left(1 \times 10^{-6} \mathrm{M}\right)$; lane 10, (+)-CC-1065 $\left(1 \times 10^{-6} \mathrm{M}\right)$. 
<smiles>Cc1csc2c1C13CC1CN(C(=O)c1cc4cc(NC(=O)c5cc6ccccc6[nH]5)ccc4[nH]1)C3=CC2=O</smiles>

\begin{tabular}{ccccc} 
Compd & $\begin{array}{c}\text { Dose } \\
\mu \mathrm{g} / \mathrm{kg}^{\mathrm{a}}\end{array}$ & $\begin{array}{c}\text { MSP } \\
\text { days }^{\mathrm{b}}\end{array}$ & $\mathrm{T}^{\mathrm{C}} \mathrm{C}^{\mathrm{c}}$ & $\begin{array}{c}\text { Surviving } \\
\text { Mice }^{\mathrm{d}}\end{array}$ \\
\hline none & 0 & 16.7 & 100 & $0 / 6$ \\
\hdashline $\mathbf{3 0}$ & 10 & $>60$ & $>360$ & $4 / 6$ \\
30 & 30 & $>53$ & $>320$ & $3 / 6$ \\
\hline
\end{tabular}

${ }^{a}$ Dose $(\mu \mathrm{g} / \mathrm{kg}$ wt. of animal) administered i.p. on days 1,5 , and $9 .{ }^{b} \mathrm{MSP}=$ Mean Survival Period (days). ${ }^{\mathrm{C}} \mathrm{T} / \mathrm{C}=$ Treated/Control (MSP) $\times 100 .{ }^{\mathrm{d}}$ No. of live animals after 80 days when terminated.

Figure 12.

In vivo antitumor activity (L1210, i.p.). 


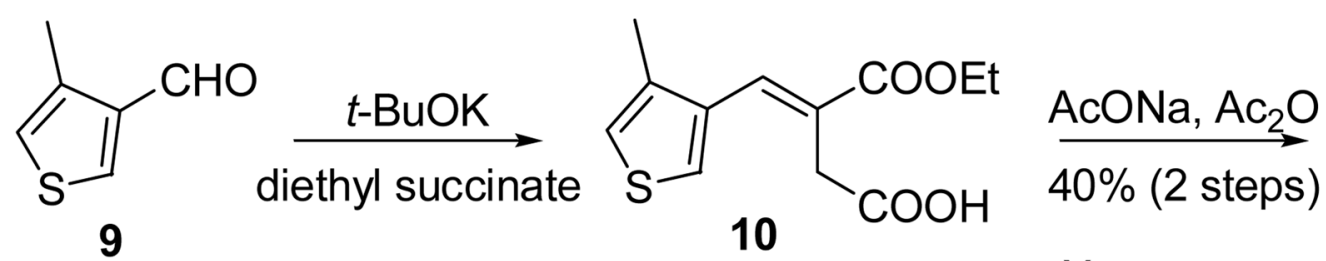<smiles></smiles>

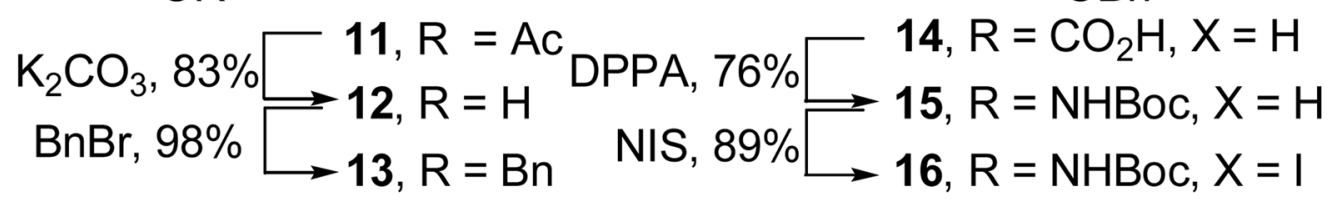

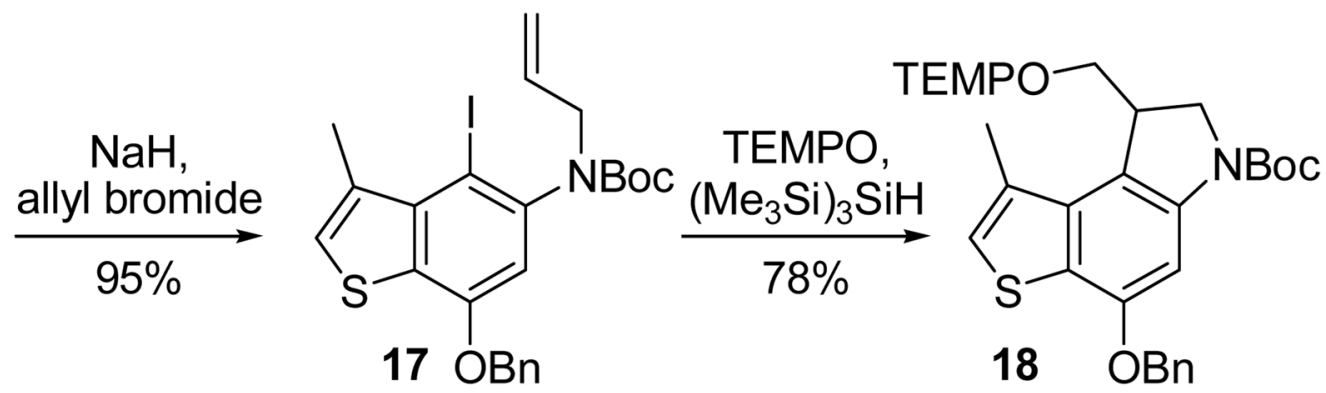

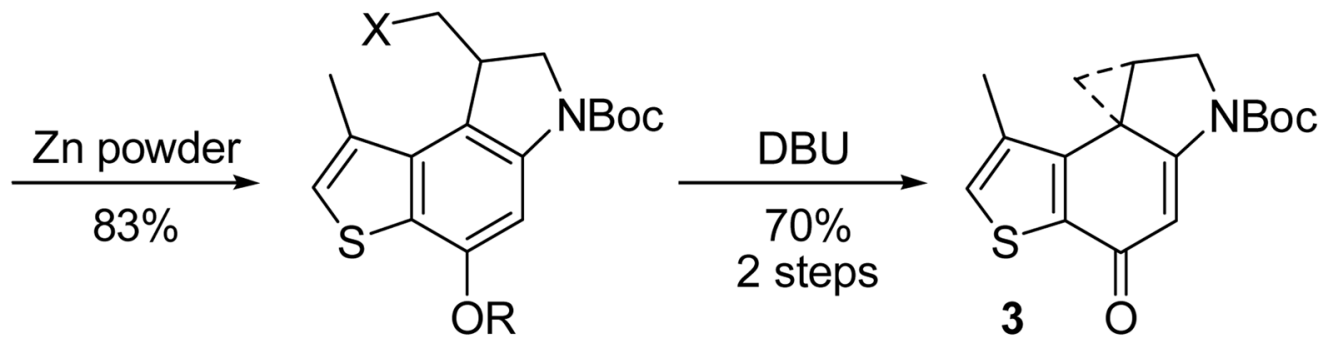
$\begin{aligned} & \mathrm{PPh}_{3}, \mathrm{CCl}_{4}, 95 \% \square \text { 19, } \mathrm{R}=\mathrm{Bn}, \mathrm{X}=\mathrm{OH} \\ & \mathrm{Pd} / \mathrm{C}, \mathrm{HCO}_{2} \mathrm{NH}_{4} \longrightarrow \mathbf{2 0}, \mathrm{R}=\mathrm{Bn}, \mathrm{X}=\mathrm{Cl} \leftarrow \text { Chiralcel OD } \\ & \mathbf{2 1}, \mathrm{R}=\mathrm{H}, \mathrm{X}=\mathrm{Cl} \quad \text { resolution, } \alpha=1.3\end{aligned}$

Scheme 1. 
<smiles>Cc1csc2c(O)cc3c(c12)C(CCl)CN3C(C)(C)C</smiles>

1) $\mathrm{HCl}-\mathrm{EtOAc}$ 2) $22, \mathrm{EDCl}$ $92 \%$
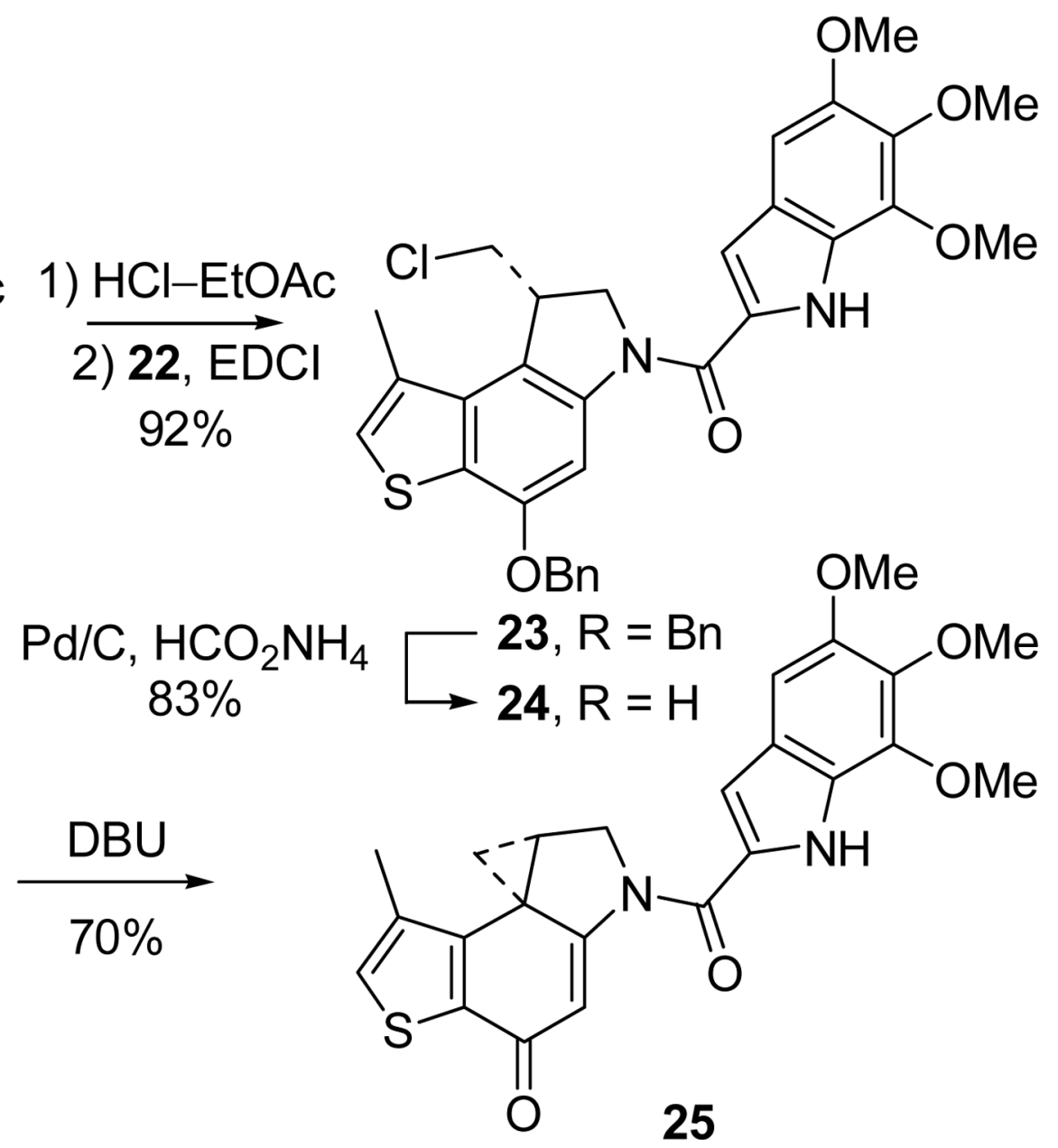

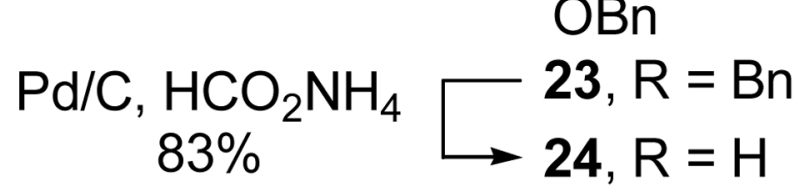

Scheme 2. 


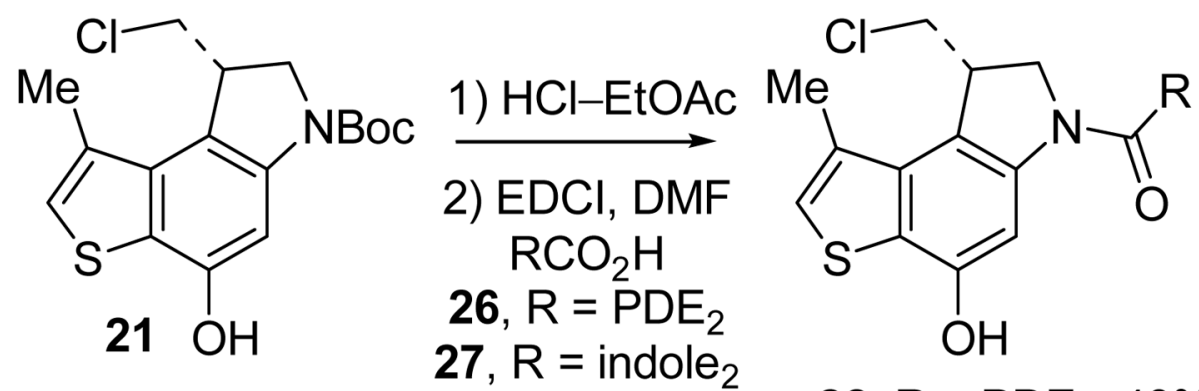

28, $\mathrm{R}=\mathrm{PDE}_{2}, 40 \%$

29, $R=$ indole $_{2}, 72 \%$<smiles>[R]C(=O)N1CC2CC23C2=CC(=O)c4scc(C)c4C23C1</smiles>

8, $\mathrm{R}=\mathrm{PDE}_{2}, 81 \%$

30, $\mathrm{R}=$ indole $_{2}, 46 \%$<smiles>COc1c(O)c2c(c3cc(C(=O)N4CCc5c4c(O)c(OC)c4[nH]c(C(C)=O)cc54)[nH]c13)CCN2C(N)=O</smiles>

indole ${ }_{2}$<smiles></smiles>

Scheme 3. 

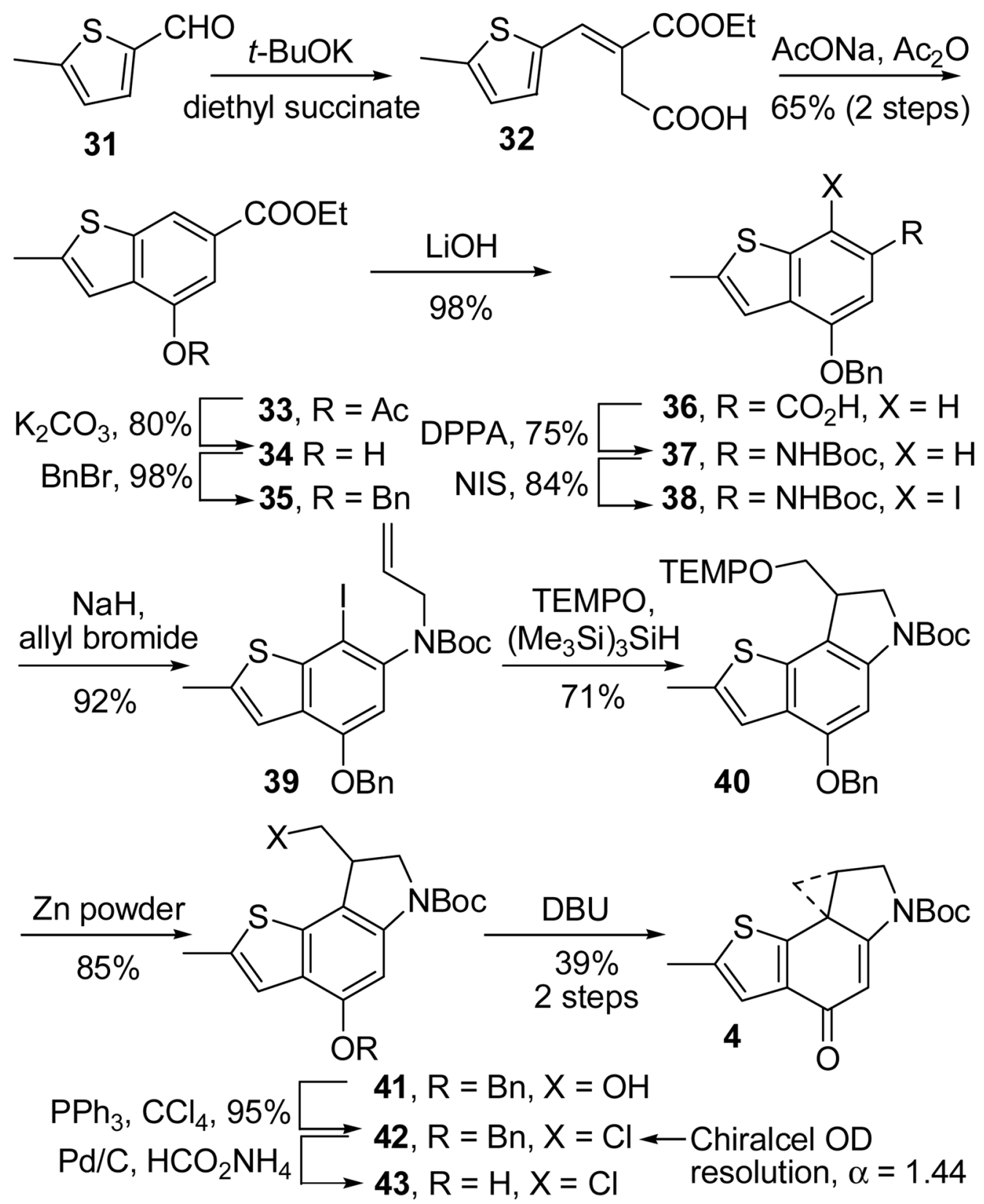

Scheme 4. 


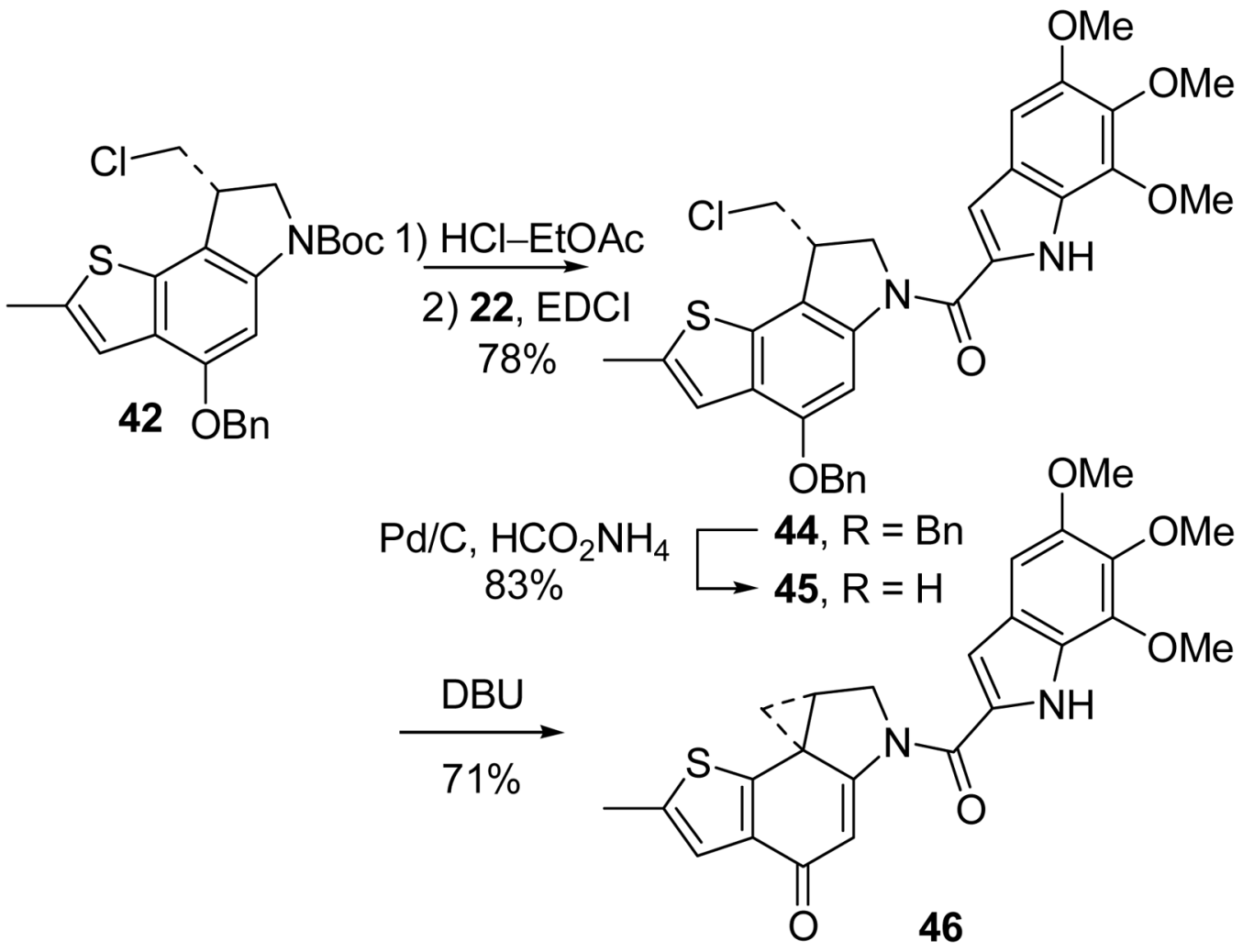

Scheme 5. 